\title{
Managing Change with Integrity in Malaysian Institution of Higher Education
}

\author{
Siti Akmar Abu Samah \\ Universiti Teknologi MARA, MALAYSIA \\ Tel: 0166396407 E-mail: sitiakma@salam.uitm.edu.my
}

Hj. Kamaruzaman, J (Corresponding author)

Faculty of Forestry, Universiti Putra Malaysia, 43400 UPM, Serdang, Selangor, Malaysia

Tel: 60389467176 E-mail: kamaruz@putra.upm.edu.my

\begin{abstract}
Change is a perennial buzzword in today's world. In every facet of life that all of us undergo, will constantly and consistently meet the condition of change. When it happens, this chain of action will attract reaction of various multitudes which could either be desirable or undesirable. With every noble intention, change is supposed to improve, enhance and upgrade the aspects of living so that everyone in the organisation will benefit for its very existence. In the educational institution, the members in the organization inevitably face the challenges, be those imposed or designed, must learn to adapt or adopt to meet the demand. Change that takes place within as well as outside the institution can culminate mixed reception and perception among the clients. This paper attempts to explore the issues of integrity and the challenges that educational institution like that of Universiti Teknologi MARA faces in managing change.
\end{abstract}

Keywords: Change, Educational institution, Integrity, Challenges, Managing change

\section{Introduction}

Change to its very meaning refers to alteration, variation and conversion. The interest in the nature of change happens habitually in life. It does not only occur in organic cycle, but also in the inorganic cycle which evolves around us in our daily living. Living things change according to time, space, environment and condition of which they need to survive. In order to sustain existence be it organic or inorganic, change must take place. It is suffice to state that elements of inorganic structure particularly, evolve around change for its continuous existence.

As for higher education, the need to change is so inevitable due to the need to survive and to remain relevant. Competition happens overnight with the mushrooming of private institutions of higher learning offering academic programmes similar to those establishments of several government-run institutions and universities. Many of these private institutions offer programmes that are attractive and flexible in which market for the enrolment of prospective students is ever ready for them. With these private-run institutions, money churning strategies allow them to import expertise and experts who can enhance the product marketability.

Another force of change that institutions of higher education in Malaysia have to face is the aspiration to achieve that is to be recognized globally and that also to attain world class status. This objective which is aspired by every university in the country calls for change to take place. In order to do this, the institution of higher education has to meet the requirements that can render it world class status. Some of the initiatives include internationalization and recognition from top-notch world organization in the aspects of research, innovation, entrepreneurship and creativity. In doing so, change has to remain constant at all times. In addition, it is necessary to change as institutions such as Universiti Teknologi MARA has to make continuous national contributions in various aspects - socio-economic in particular, as these will become part of nation growth and nation building. To fulfill this obligation, educational institutions of higher learning have to be able to determine the mechanism of which change can occur. It requires the ability to identify the mechanism, how to implement and operate as well as finally, to be able to make lucrative contributions to the fullest. The need of knowing how to implement new excellent ideas is critical since good ideas will be wasted of one does not know how to do it well.

To be able to emulate successful organization in managing ideas for change to take place, it is helpful to look into mechanism that may promote the initiative. In the book "The Heart of Change" by Kotter and Cohen (2002), highlighted eight steps for successful change as illustrated in Table 1. 


\section{Change management with integrity in facing challenges}

When change has to occur, it can never be left in peace. To a certain extent, when change happens, the human community is forced to shift condition which can sometimes be unpleasant (Kotter, 1996). This initiative attracts reactions. At the tertiary level, when the buzzword is flashed, the involvement ranges from the issues of leadership, people, environment, technology and finance. As the organization plans for amendments or change to take place, these issues need to be addressed in accordance with the information dissemination, implementation strategies and continuous commitment. As the teaching staff of local universities, the authors have the liberty to observe the scenario for the last two decades. It is of great importance that these issues be managed effectively and efficiently in order for the initiative to realize eventually, harmoniously.

\subsection{Leadership Credibility}

For change to happen, leaders at the helm have to be clear of the directions that they are spearheading the followers to take. Leaders by definition (Harvard Business Essentials, 2003)

"...create an appealing vision of the future and then develop a logical strategy for making it a reality. This also motivates people to pursue the vision, even in the face of obstacles."

In enjoining them, managers of educational institution have to work hand in hand particularly in the implementation and operational strategies for change to occur. It is useful to note Kotter's (1996) outline in Table 2 which he states that there are possibilities in the following outcomes that may be encountered by leaders and managers in managing change. (See Table 2)

As both leaders and managers are the prime shaper and mover of the change agenda, the initiative must come together with moral values and ethics that should become the pillar of strength and stability, Thus, integrity in its place will help the leader and manager conduct their obligation which can inspire the people factor in the organization. In the concept of change, leadership retains its credibility by ensuring that there are no top-down exhortations and, at the same time, having the ability to control aimless bottom-up improvisations.

\subsection{People focused}

Educational institutions, the public university in particular, like any other organisations comprise a population of people of varying level of academic qualifications, of different expectation and perception and varying beliefs and commitment. The member of this organisation such like the academicians, students and support staff as well as stakeholders and other interested parties make up the composition of agents for change. As far as Universiti Teknologi MARA is concerned, the government factor too is important as it lies here, the aspiration of the country's leaders, who profess that the socio-economic status of the population remains competitive. In this commitment, the University has to be dynamic in change and constantly adjusting to current needs and drives.

To effectively manage change, responses also have to come from the two major groups of people of the institutions: the academicians and the students. As they are very much involved as the life line in the University's operational strategy, considerations on the following pertinent elements must not be compromised. These include curriculum, teaching method, learning style as well as human resource and administrative requirements. In order for change to happen in the University, the above factors should be the basis of principles that should not be ignored.

Harvard Business Essentials (2003) had made suggestions that may be helpful in terms of motivating the people factor to handle organisational change. These include among others:

(1) Encourage innovative thinking

(2) Delegate and not micromanage

(3) Extend trust

(4) Be flexible and extend that flexibility to others at the first opportunity

(5) Encourage risk taking and be tolerant of failures

(6) Spread decision-making authority around

These are strategies that may help to promote gradual acceptance to change. Since resistance is another barrier that will impede the change initiative, in the university, it will be very useful that in the later section of the paper that a discussion be put forth, that is the issue on curriculum change. With the advent of economic and social factors arising from technological, international integration, extensive opportunities, the university is usually challenged by the inadequacy of the curriculum designed and the graduates that it produces. Hence, there is the need for curriculum review at regular interval of every five years, which is commonly practiced in local university.

\subsection{Environmental sanctity}

Universiti Teknologi MARA has evolved historically, socially and economically from its humble beginning as Maktab RIDA in 1956, Institut Teknologi MARA since 1967 and now a university since 1999. As its status now, tremendous growth has taken place up to this very day with the implementation of the Ninth Malaysia Plan, a governmental master 
plan, in which every chapter of the blueprint emphasizes the achievement of the objectives, in terms of the function of the branch campuses, faculties, centres of learning, institutes, units and how all these assist in the development of the academics, students, management, research, information and communication infrastructure and facility management.

With the Ninth Malaysian Plan, implementation of change has to take its course, with or without resistance. This will then require effective management of change for the organization to be steered towards the directions the stewardship wants it to flow to. A clear understanding of these directions has to be in place by the leaders and the people, so that the very existence of the university remains relevant and competitive. This endeavor should be able to motivate the human factor to support change.

\subsection{Technology with accountability}

Wherever change is a priority, another impact that can be identified is on the technological factors which require first-at-hand basis of change management. In the university, learning is the trade of the market and online information acquisition is in today's demand. In online learning, there are a variety of relevant applications of technologies which are useful for powerful and effective learning.. These include simulations, interactive learning, online search and retrieval, electronic surveys, online video with discussions just to name a few. These capabilities come with cost, energy and expertise of which change towards this, if not properly planned and managed may result in several inadequacies and frustrations.

Simultaneously, in the learning system, technology has taken centre stage whereby lecturers have included various instructional materials which student can access anytime and anywhere. This has also allowed the sharing of knowledge and communication among lecturers made very feasible and simple. In Malaysia, the pursuant of e-learning has been striving hard to ensure that it takes off very well with everyone in the educational institution. The target population, namely the lecturers who are responsible in uploading the content material of the course taught and the students responsible for the downloading and usage of content material for their very own purpose, has been continuously given training, demonstration and courses to help them get started and to move on. The approach in teaching and learning in institutions of higher education needs to accommodate to this drive for e-learning, hence change is inevitable.

\subsection{Financial truce}

After all, the following agents of change: leadership, people, environment and technology are mobilized in every which way, with the state of finance that every organisation has to account for. In the case of Universiti Teknologi MARA, managing of change has been airbrushed by the support of the government, being a public university with the largest student enrolment - at 100000 currently, stakeholders as well as successful alumni that have been the product of the university since the initial establishment in the 1950's. Nevertheless, concerted effort has been put in to generate self-income by the university itself, apart from the dependence on the governmental budget. In its change effort, the university has established a business entrepreneurship of its own called UiTM Holdings with the stewardship of an appointed Chief Executive Officer.

With the changes that have to be constant, managing this initiative is a big task for every member of the university. Every sector in the business entity above, is very much involved with the issues discussed in the paper. The human factor drives the maintenance of credibility and integrity in running these establishments successfully.

\section{Selected sample case study on change management: The case of UiTM}

It is useful to take note of details that will help the organization, UiTM in particular, to consider, in its effort to manage change. From an article by Jones et al (2004), a list on principles of change management seems helpful. However, it is pertinent to note too that there is no single methodology that can fit every organization, what more an institution of higher learning. Then again, there are sets of practices, tools and techniques that can be adapted according to various situations, among the guiding lines, Jones et al. (2004) had outlined the following in Table 3 which may be of assistance in the management of change in an organisation. ( See Table 3)

In the discussion below, a case sample is displayed in terms of curriculum review effort undertaken by the Academy of Language Studies, Universiti Teknologi MARA during the late 1990's, which since then has brought about changes as far as teaching of English language is concerned. Academy of Language Studies or prior to 2003 has been known as the Language Centre (Pusat Bahasa) and has undertaken curriculum review exercise every five years The recent one was in 1999. In managing this academic change, the people factor is given the initial consideration and these are the academic managers, lecturers and students. In this exercise the managers play their role effectively by providing clear information based on calculated judgment and facts for the need to have a curriculum review.

Prior to the exercise, the Ministry of Education, Malaysia introduced the Malaysian University English Test (MUET) for diploma-level students to sit for and to pass before they are accepted for entrance to the degree programme. To meet this requirement, the academic managers were well-informed and self-directed to carry out the change. The move was made clear to every responsible party in the organization. A staff meeting was called. This involved the academic and 
the administrative staff, all of whom were informed of the impending change. It was received with mixed feelings as the teaching staff, especially, apart from other work obligation, has to slowly adapt to the new requirement. Within a certain time frame, textbook writers were selected and directed to publish homegrown teaching materials to complement the curriculum change.

In the communication process, the academicians were regularly informed of the progress made by the curriculum committee as well as the textbook writing team. Through this constant address by the academic managers to the staff, the mammoth change that took place in early 1999 was able to see results when the new curriculum was adopted coupled with the completion of writing the textbooks in the middle of 1999. With the accomplishment - writers were rewarded, language lecturers were provided with the new materials for teaching, student's learning was more directed and the organization has been enjoying the fruit of the labour for the past six years since. However, at the time of writing this paper, the Academy of Language Studies is in the process of reviewing the said curriculum.

This case sample is documented to indicate that large scale change can successfully take place, and in this case - the language centre. The steps in realizing the initiative was not as simple as it seemed to be. However, based on earlier discussion, issues on leadership, people, environment, technology and finance were dealt with surely well, for the major change in the Academy of Language Studies to take place.

\section{Conclusions}

Albert Schweitzer once said, "Example is not the main thing influencing others. It is the only thing." Over and again, the world has seen organisations change successfully and unsuccessfully during the process of transformation. From the discussion above, the current change agents have to maintain high integrity for transformation to happen effectively. Their sense of purpose to remain relevant will make them enlighten to continuously work together for the good of the organizations. One block of hindrance that mangers of change must never ignore is the emotional shift: from those emotions that hinder change and those that facilitate change. The leaders/managers have to be prepared with facing anger, pessimism, cynicism, anxiety and insecurity. Therefore, leaders and mangers by exemplary models help to change these emotions to those of trust, optimism, enthusiasm and hope.

The power of the people is another crucial agent for change to take place. Leaders need to address the initiative to colleagues and subordinates very clearly of the need for change. The establishment of relevant committees to assist the management is another approach to attract the people to work together to achieve a shared vision for the university. It is the centre of learning to play its role effectively and efficiently.

Finally, the crucial ingredient that mobilizes change is finance. Thus, University has taken a very proactive step in generating income for its sustainability. The dynamics of this effort involve competence of the university treasury, product supplier's credibility and maintenance provider. In managing transformation in the university, financial distribution and re-generation has to be done fairly, with transparency and clear procedures. With all these issues addressed and placed in the right frame of mind and attitude, it is hopeful that any change initiatives that take place in the university will reap good for all.

\section{References}

Harvard Business Essentials, (2003). Managing Change and Transition, USA: Harvard Business School Publishing

Holt, M. (1987). Judgement, Planning and Educational Change, UK: Harper and Row Ltd

Jones, J., Aquire, D. and Calderone, M. (2004). Ten Principles of Change Management, USA: Booz Allen Hamilton Inc.

Kotter, J.P. (1996). Leading Change USA: Harvard Business School

Kotter, J.P. and Cohen, D. (2002). The Heart of Change USA: Harvard Business School Publishing

Maxwell, J.C. (2004). Thinking for a Change, USA: Warner Books Inc. 
Table 1. The eight steps for successful change

\begin{tabular}{|l|l|l|}
\hline Step & Action & New Behaviour \\
\hline 1 & Increase urgency & $\begin{array}{l}\text { People start telling each other, "Let's go, we need to } \\
\text { change things!" }\end{array}$ \\
\hline 2 & Build the guiding team & $\begin{array}{l}\text { A group powerful enough to guide a big change is } \\
\text { formed and they start to work together well. }\end{array}$ \\
\hline 4 & Get the vision right & $\begin{array}{l}\text { The guiding team develops the right vision and } \\
\text { strategy for the change effort. }\end{array}$ \\
\hline 5 & Empower action & $\begin{array}{l}\text { People begin to buy into the change and this shows in } \\
\text { their behaviour. }\end{array}$ \\
\hline 6 & Create short term wins & $\begin{array}{l}\text { More people feel able to act, and do act on the vision. } \\
\text { Momentum builds as people try to fulfill the vision, } \\
\text { while fewer and fewer resist change. }\end{array}$ \\
\hline 7 & Don't let up & $\begin{array}{l}\text { People make wave and wave of changes until the } \\
\text { vision is fulfilled. }\end{array}$ \\
\hline 8 & Make change stick & $\begin{array}{l}\text { New and winning behaviour continues despite the } \\
\text { pull of tradition, turnover of change leader etc. }\end{array}$ \\
\hline
\end{tabular}

Table 2. Outcomes of managing change

\begin{tabular}{|l|l|}
\hline 1 & $\begin{array}{l}\text { Transformation efforts can be successful for a while, but often fail after } \\
\text { short term }\end{array}$ \\
\hline 2 & Results become erratic \\
\hline 3 & $\begin{array}{l}\text { Transformation efforts go nowhere } \\
\text { All highly successful transformation efforts combine good leadership with } \\
\text { Shood management. } \\
\text { and acquisitions. } \\
\text { But real transformation programmes have trouble getting started and major } \\
\text { long term change is rarely achieved. }\end{array}$ \\
\hline
\end{tabular}

Table 3. Principles of change management

\begin{tabular}{|l|l|}
\hline Principle & Guiding Line \\
\hline 1 & Address the human side systematically \\
\hline 2 & Start at the top \\
\hline 3 & Involve every layer \\
\hline 4 & Make change a formal case \\
\hline 5 & Create ownership \\
\hline 6 & Speak to the individual \\
\hline
\end{tabular}

